\title{
An Analysis of Continuity of Care Implementation at Tarus and Baumata Public Health Center, Kupang Regency
}

Rose Virgine Tuto Boli ${ }^{1 *}$, Mariana Dinah Charlota Lerik ${ }^{2}$, Muntasir $^{3}$, Imelda F. E Manurung ${ }^{4}$, Agus A. Nalle ${ }^{5}$

${ }^{1}$ Public Health Sciences Students, Post-Graduate Program, Nusa Cendana University, Kupang-85001, East Nusa Tenggara, Indonesia

${ }^{2,3}$ Public Health Sciences Lecturer, Post-Graduate Program, Nusa Cendana University, Kupang-85001, East Nusa Tenggara, Indonesia ${ }^{4,5}$ Public Health Sciences Lecturer, Post-Graduate Program, Nusa Cendana University, Kupang-85001, East Nusa Tenggara, Indonesia

Article History
Received: 10.11 .2020
Accepted: 24.11 .2020
Published: 28.11 .2020
Journal homepage:
https://www.easpublisher.com
Quick Response Code

Abstract: An analysis of Continuity of Care implementation at Tarus and Baumata Public Health Center, Kupang Regency was conducted to analyze the implementation of midwifery care during pregnancy, childbirth and postpartum towards quality midwifery care acts partially and simultaneously. This study is a mixed method study using a concurrent model. This research used quantitative research using cross sectional design and qualitative research using case control design. Samples were 52 mothers who had babies aged 40 days to 2 months at Tarus and Baumata Public Health center taken using a purposive sampling technique. The instrument used was a structured questionnaire and interview methods, documentation, recording, and recording to support the data. Hypothesis test results showed that $\mathrm{H}_{1}, \mathrm{H}_{2}$ and $\mathrm{H}_{4}$ are accepted but $\mathrm{H}_{2}$ is rejected. The results showed that midwifery care during pregnancy and postpartum had a partial effect on midwifery care quality which have Sig. value $0,000<0,05$, while midwifery care during childbirth has no partial effect on midwifery care quality which have Sig. value $0,271>0,05$. However, midwifery care during pregnancy, childbirth, and postpartum have an effect on midwifery care quality simultaneously which have Sig. value $0,000<0,05$. Midwifery care during pregnancy and postpartum have been carried out in accordance with the standards of midwifery care quality at Tarus and Baumata Public Health Centre. Meanwhile, midwifery care during childbirth has not been carried out according to midwifery care quality standards.

Keywords: Pregnancy, childbirth, postpartum, midwifery care quality, public health center.

Copyright (C) 2020 The Author(s): This is an open-access article distributed under the terms of the Creative Commons Attribution 4.0 International License (CC BY-NC 4.0) which permits unrestricted use, distribution, and reproduction in any medium for non-commercial use provided the original author and source are credited.

\section{INTRODUCTION}

The quality of maternal and infant health services is determined by the management of midwifery care on an ongoing basis through a systematic problemsolving process, starts from the analysis of data (subjective and objective data) are analyzed in order to get actual and potential midwifery diagnoses, problems and needs, planning, implementation, until evaluation [1]. This requires midwifery to use competence and think critically in order to enforce a proper midwifery diagnosis so that will achieve proper decision making and quality care [2].

East Nusa Tenggara Provincial Health Department data on the achievement of Minimum Service Standards shows that there are 5 most contributed places in maternal and infant mortality rates, namely TTS, Alor, Kupang, Belu, and Sikka Regencies. There are 11 cases of maternal mortality and 86 cases of infants in Kupang Regency itself [3]. Meanwhile, Kupang Regency also contributed to maternal and infant mortality in 2019 with a total of 5 maternal and 74 infant deaths in last 8 months [4]. Previous study at The Health Department of Kupang Regency showed that the collection of data on the health of pregnant women often delays, incomplete data filling and long data presentation to make quick and precise decision, so that affected their administrative records.

There are 2 dichotomous Public Health Centers beacause they are directly adjacent to the working area of Kupang City, which are Tarus and Baumata Public Health Centers. People can choose where they want to take care their pregnancy until postpartum although it is not their administrative areas to access health services during pregnancy, childbirth, and postpartum. The aims of this research are to analyze the implementation of Continuity of Care (COC) during pregnancy, childbirth, and postpartum partially and simultaneously. Scope of this research is $\mathrm{COC}$ on mothers who have baby from aged 40 days to 2 months at Tarus and Baumata Public Health Center. 


\section{MeTHODS}

This study is a mixed method research with a concurrent model, where researcher combines the results of research from one method to another at the same time [5]. Quantitative research used cross sectional design and qualitative research used case control design with a retrospective approach for both of them. This study used cluster sampling (area sampling) which the determination of the sample used purposive sampling technique. Samples are mothers who have babies aged 40 days to 2 months at Tarus and Baumata Public Health Center, total 52 mothers on quantitative research and midwives who provide midwifery care on qualitative research.

Data collection was carried out at Public Health Center of Tarus and Baumata, Kupang Regency for a month (September-October), since the research letter was issued by the University of Nusa Cendana. Data analysis technique used in this study was multivariate analysis using multiple correlation coefficients as follows:

$$
\begin{array}{ll}
\mathbf{Z}=\boldsymbol{\alpha}+\boldsymbol{\beta}_{\mathbf{1}} \mathbf{X}_{\mathbf{1}}+\boldsymbol{\beta}_{\mathbf{2}} \mathbf{X}_{\mathbf{2}}+\boldsymbol{\beta}_{\mathbf{3}} \mathbf{X}_{\mathbf{3}} \ldots \boldsymbol{\beta}_{\mathbf{n}} \mathbf{X}_{\mathbf{n}}+\boldsymbol{\varepsilon} \\
Z & \text { : } \text { Quality Midwifery Care } \\
\alpha & \text { : Constant } \\
\beta_{1} & \text { : Regression coefficient for X1 } \\
\beta_{2} & \text { : Regression coefficient for X2 } \\
\beta_{3} & \text { : Regression coefficient for X3 }
\end{array}
$$

$\mathrm{X}_{1} \quad$ : First independent variable

$\mathrm{X}_{2} \quad$ : Second independent variable

$\mathrm{X}_{3} \quad$ : Third independent variable

$\mathrm{B}_{\mathrm{n}} \quad$ : Regression coefficient

$\mathrm{X}_{\mathrm{n}} \quad$ : Independent variable

$\varepsilon \quad:$ Error / residual $(0.05)$

If the percentage of the relationship between independent and dependent variables partially and simultaneously are more than $50 \%$ and the significance values are more than 0,05 , means that midwives are responsible for and carry out or perform better quality midwifery care to mothers from pregnancy, childbirth, and postpartum, vice versa. This research has received approval from the Health Research Ethics Commission issued by the Faculty of Medicine, Nusa Cendana University Kupang on October $14^{\text {th }}, 2020$.

\section{ReSUltS}

The results of quantitative research obtained from distributing questionnaires to 52 mothers who participated in this research. Then, it will be calculated using multiple regression coefficients in SPSS 24 and saw the value of the relationship between independent and dependent variables partially and simultaneously.

\begin{tabular}{|c|c|c|c|c|c|c|}
\hline \multicolumn{7}{|c|}{ Model Summary } \\
\hline Model & $\mathbf{R}$ & R Square & Adjusted R Square & \multicolumn{3}{|c|}{ Std. Error of the Estimate } \\
\hline 1 &, $801^{\mathrm{a}}$ & 0,642 & 0,619 & \multicolumn{3}{|c|}{0,704} \\
\hline \multicolumn{7}{|c|}{ a. Predictors: (Constant), Postpartum, Childbirth, Pregnancy } \\
\hline \multicolumn{7}{|c|}{ ANOVA $^{\mathrm{a}}$} \\
\hline \multicolumn{2}{|l|}{ Model } & Sum of Squares & df & Mean Square & $\mathbf{F}$ & Sig. \\
\hline \multirow[t]{3}{*}{1} & Regression & 42,697 & 3 & 14,232 & 28,676 &, $000^{b}$ \\
\hline & Residual & 23,823 & 48 & 0,496 & & \\
\hline & Total & 66,519 & 51 & & & \\
\hline & & \multicolumn{5}{|c|}{ a. Dependent Variable: Midwifery Care Quality } \\
\hline & & \multicolumn{5}{|c|}{ b. Predictors: (Constant), Postpartum, Childbirth, Pregnancy } \\
\hline & & \multicolumn{5}{|c|}{ Coefficients $^{\text {a }}$} \\
\hline \multirow{2}{*}{\multicolumn{2}{|c|}{ Model }} & \multicolumn{2}{|c|}{ Unstandardized Coefficients } & Standardized Coefficients & $\mathbf{t}$ & Sig. \\
\hline & & B & Std. Error & Beta & & \\
\hline \multirow[t]{5}{*}{1} & (Constant) & $-2,252$ & 2,208 & & $-1,020$ & 0,313 \\
\hline & Pregnancy & 0,162 & 0,034 & 0,503 & 4,776 & 0,000 \\
\hline & Childbirth & 0,069 & 0,062 & 0,105 & 1,112 & 0,271 \\
\hline & Postpartum & 0,334 & 0,089 & 0,371 & 3,765 & 0,000 \\
\hline & \multicolumn{6}{|c|}{ a. Dependent Variable: Midwifery Care Quality } \\
\hline
\end{tabular}
Furthermore, researcher analyzed how the relationship between those variables occurred using the results of interviews obtained from of the qualitative research results. The output of SPSS 24 can be seen as follows:

Table-1: Quantitative Research Output

Based on table 1 (Coefficients ${ }^{\mathrm{a}}$ ) above, it can be seen that Pregnancy and Postpartum variables have relationship to Midwifery Care Quality standards partially. This can be seen from the significance value of the two variables which is less than 0,05 which is 0,000. Meanwhile, Childbirth variable does not have relationship to Midwifery Care Quality standards partially which can be seen from the significance value more than 0,05 , that is 0,271 . The three independent variables simultaneously have a positive and significant effect to the dependent variable. This can be seen from table 1 (ANOVA) where the independent variable has a significance value less than 0,05 that is 0,000 with simultaneous effect value (R Square) of 0,642 or 64 , 


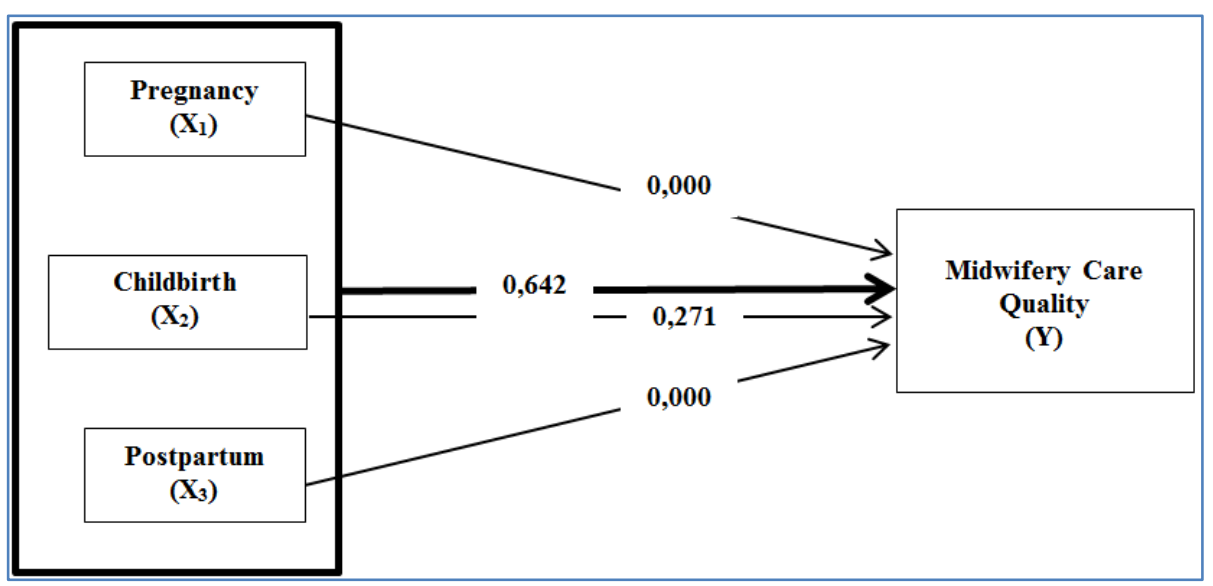

Fig-1: Diagram of Variables' Value Partially and Simultaneously

\section{DisCUSSION}

\section{Relationship between Pregnancy and Midwifery Care Quality}

The results show that there is a relationship between Pregnancy and Midwifery Care Quality with a significance level of $p$-value $=0,000$. It is supported by the results of interviews to midwives who responsible for midwifery care services. She stated that, " $K 1$ is the first time visit in pregnancy period and it has the highest number of visits than $K 4$ or postpartum visit. That's because most them only live temporarily in this area. They come, check, get registered, then they move. So, most of them transit in that area. That's why their $K 2, K 3$, and $K 4$ don't exist ..."

This research is in line with research conducted by Nuryawati et al. [6] who states that less than half $(28,6 \%)$ of pregnant women in the work area of the UPTD Panyingkiran Public Health Center, Majalengka Regency in 2016 were incomplete in conducting K4 visits for pregnant women. Antenatal Care is focused on the $\mathrm{K} 1$ visit because mothers can consult about her conditions and situations that can potentially threaten the fetus and the mother herself on early age. It is important because midwives can determine target the examination taken on pregnant women based on her pregnancy age. However, if the visit schedule is missed, it can be checked again based on the previous visit because each schedule has different quality and quantity of service. Therefore, midwives of Tarus and Baumata Public Health Center prioritize the quality of visits than its quantity.

There were also mothers who did not come for the $\mathrm{K} 1$ visit caused by their beliefs, myths, and their house distance to the nearest health facility. In order to solve this and plus the Covid-19 pandemic, midwives can supervise and monitor pregnant mothers by phone or WhatsApp. If a mother does not have a phone, then a home visit will be carried out, but still pay attention to health protocols, so the safety of the mother and baby is maintained, even though the distance from health facility to their house is quite far.

One important aspect is building a good and strong relationship with the mother and her family. If a mother trusts a midwife, she will return to the same midwife for her childbirth process in health facility. Pregnancy examination and monitoring standards are aimed to provide a good quality of antenatal or pregnancy care and early detection of pregnancy complications. Therefore, midwives should provide at least 4 times of pregnancy services, the examination includes anamnesis and careful monitoring of the mother and fetus to assess whether development is normal, midwives must also recognize chronic pregnancies or abnormalities, especially anemia, malnutrition, hypertension, infectious sexual diseases, Human Immunodeficiency Virus (HIV), provides immunization services, health advice and education as well as other related acts given by the Public Health Center.

\section{Relationship between Childbirth and Midwifery Care Quality}

The results show that Childbirth and Midwifery Care Quality does not have relationship partially because it has a significance level of $p$-value $=0,271$. This is supported by the results of researcher's interviews with midwives who responsible for quality midwifery care standard there. Most of them faced about the same thing that is about partograph filling during childbirth and Early Initiation of Breastfeeding. When researcher asked about partograph, they answered,"...We have those who can fill in the partograph, but it is not quite accurate..."; "We can. But some don't much understand how to fill it"; "About $70 \%$ of midwives can fill the partograph accurately. But $30 \%$ seems like to learn more. Sometimes we fill it after the birth process". 
This research is not in line with the results of Toemandoek et al. [7] research who said that from 33 respondents, 30 respondents $(90,9 \%)$ knew how to fill in partographs, 2 respondents $(6,1 \%)$ had sufficient of knowledge, and 1 respondent $(3,0 \%)$ who lacked of knowledge. The partograph consists of 3 components which are fetal records, childbirth progress, and maternal records which can be considered as an "early warning system" which will assist in early decision making when a mother should be referred, expedited or ended her childbirth process.

This study is in line with Silfia [8] who stated that 8 of 15 midwives $(53,3 \%)$ who did not attend Normal Pregnancy Labor (NPL) training did not fill partograph quite right, while 2 of $15(13,3 \%)$ midwives who attended NPL training filled the partograph correctly. It means midwives who did not attend NPL training less accurate in filling partograph than midwives who did it.

According to problems above, Health Department of Kupang Regency took action to carry out NPL training for midwives who do not quite understand about proper and correct ways to fill partograph and it run quite well. Partograph filling is one of the most important things that acquires full attention during childbirth process because it is a direct report or documentation of childbirth process. Midwives also see what risks might occur and take appropriate action according to the problems faced from partograph. This documentation is very important especially in making right preventive decisions at stage IV. In addition, a completely proper and correct patograph records can be used as a reference to determine and monitor the extent of INC implementation that is carried out safely and cleanly.

Monitoring supervision carried out by Midwife Coordinator to patograph filling remains less of implementation so that cause midwives do not use partograph efficiently as a means of monitoring childbirth progress. The existence of Midwife Coordinator will motivate and increase midwives' discipline in doing their job based on procedures and regulations (monitoring childbirth progress using partograph). However, not all midwives were monitored by Midwife Coordinator so that there were still midwives who do not know use a partograph.

Midwives must master the proper and correct way in filling partographs so midwifery care quality in childbirth phase can be well-maintained and reduce risks when enter stage IV. In addition, they can help maternal childbirth process clean and safe. They must practice and perform the partograph filling then her supervisor needs to give feedback to that in order to know their skills whether it is correct or not.

\section{Relationship between Postpartum and Midwifery Care Quality}

The results show that there is a relationship between Postpartum and Midwifery Care Quality with a significance level of $p$-value $=0,000$. This is supported by the results of interviews to midwives who responsible for midwifery care services. When asked about the postpartum visit, the response was, "Most of the first postpartum visits were conducted at Public Health Center because they have taken care for 6 hours to 2 days after childbirth. So the mother is still here (Public Health Center) and we claim that visit taken at that time. But if the pregnancy was today, she would come home tomorrow, and after that she would go to "Pustu" and if the "pink book" and postpartum records haven't filled yet, we will count postpartum record here (Pustu)".

According to midwives as respondent, mothers do postpartum and child visits in average because they can monitor mother's health after childbirth. Postpartum visits' records are first visit is 6 hours to 2 days, second visit is 7 to 12 days, and third visit is 29 to 40 days. Most mothers do only the first and second visits because in the third visit midwife waits for them at Public Health Center to consult and install family planning. The postpartum visit register is signed and held by midwife and the mother herself ("We have postpartum at "Pustu", so mother's name, childbirth date, child gender, child weights and heights, first postpartum visit, child visit, date. All of them are arranged by date"; "We will do home visit if the mother can't come").

This research is in line with Pinaringsih et al. [9] who stated that respondents intended to do postpartum visits above $50 \%$ that is $65,5 \%$. However, it is not in line with the research results of Akunga et al. [10] that respondents who do all four pregnancy visits will do all postpartum visits either.

Postpartum home visit has obvious advantage because it allows midwife can see and interact with mother's family in safe environment. Home visits are easy to identify complex physical and psychological adjustments. Besides that, postpartum home visit also have some limits which are expensive costs, home distance, limited midwives, and concerns about patients visiting in certain areas.

Effectiveness caring evaluation is based on identified patient when planning midwifery care. Midwives feel confident that provided caring given is effective enough, if achieved these outcomes which are: postpartum mother recovers without complications; mentions breastfeeding basic knowledge accurately; demonstrates her and her baby proper caring; and interacts with baby and family members positively. 
Relationship between Pregnancy, Childbirth, and Postpartum to Midwifery Care Quality

Pregnancy, childbirth and postpartum have relationship to Midwifery Care Quality standards simultaneously, where the significance value in ANOVA table is 0.000 with the effect value (Table 1 Model Summary) of 0,642 or $64,2 \%$. It is supported by interviews in qualitative data findings that in each phase of pregnancy, childbirth and postpartum, midwives recorded or documented all examination results and medical records ("Register and medical record, we have those. We have mother's card, maternal cohort, childbirth cards, and postpartum card"; "We record all although some of them not, sometimes. But all quite complete overall”; "...about 70\% mothers fill mother's card. We think it's good enough”).

This study is in line with Silalahi [11] who stated that midwifery care is well-maintained during pregnancy, childbirth and postpartum. Pregnancy was maintained three times and there were not obstacles until postpartum. It is also in line with Giri et al. [12] who stated that there is an effect of health service quality on Midwifery Continuity of Care $(M C o C)$ with a p-value significance level of 0.002. Respondents' perceptions of the quality of health services during pregnancy, childbirth, and childbirth found that $78.3 \%$ thought that the quality of health services they received was good, but only $63.8 \%$ of respondents achieved $M C o C$.

Mother and Child Health Revolution is carried out by collaborating between midwives and trainedtraditional healers (dukun), where they have been given supplies, materials and trained before. In condition of mother comes to complain during pregnancy, the dukun will contact midwife to come and examine the mother. Likewise during the pregnancy, the dukun will contact midwife so she can bring the mother to the nearest health facility to have childbirth. Therefore, mothers who had childbirth at health facility can show a proof of that and receive 200.000 Rupiahs from the government in postpartum period. "There is a policy, whoever had childbirth at Public Health Center or other health facilities will get money from the government. It's effective. Most mothers have childbirth at health facility; go back home; do the first postpartum visit; then the government gives money. It's 200.000 Rupiahs".

In providing midwifery care services, midwives have problems dealing with pregnancy, childbirth and postpartum which can be elaborated as follows:

\section{Pregnancy}

Most people who lived in that area are visitors. They live temporarily; distance from house to health facility is far enough; and the awareness of the mother herself.
"Well, most of them stay temporarily. They do the first and second visiting. But after that, they're gone. So, we lost communication"

"...it's hard to communicate because most don't have phone"

"...then the distance from here to their house. It's far. And their awareness is hard to tell. They still believe in traditional, customs, and cultural medication"

\section{Childbirth}

Incomplete partograph filling is the biggest issue. Therefore, the government provides a training to help midwives solving this problem.

"...sometimes we fill it (partograph) after, not during the childbirth process"

"...only a few midwives can't fill the partograph. So we send them to the training and update their knowledge about it. That's why the government made that training program"

\section{Postpartum}

Home visiting is a problem faced and lack of mothers' awareness in doing postpartum visits.

"First reason is distance, the house is far, far enough; second, mother will come to check if we told so. Must come by this date and so on; and the third, lost communication and Covid-19 pandemics

\section{CONCLUSION}

Pregnancy and postpartum are partially related to Midwifery Care Quality Standards with a significance level of $p$-value $=0,000$ while Childbirth is not because has a significance level of $p$-value $=0,271$. There still many midwives who do not understand how to fill the partographs. Furthermore, Pregnancy, Childbirth and Postpartum are simultaneously related to the Midwifery Care Quality Standards with the significance value is $0.000<0.05$ with an effect value of 0,642 or $64,2 \%$.

\section{REFERENCE}

1. Varney, H., Kriebs, J. M., Gegor, C. L. (2004). Varney's Midwifery. Journal of Midwifery \& Women's Health, 49(1), 62-63.

2. Insani, A. A., Nurdiyan, A., Yulizawati, Lusiana, E. B., Iryani, dan D., Iryani. (2016). "Berpikir Kritis" Dasar Bidan dalam Manajemen Asuhan Kebidanan. Journal of Midwifery Research and Practice. Padang: FK-UNAND.

3. Dinas, K., Kabupaten, K. (2019). Rekapitulasi Laporan Ibu Bersalin dan Nifas di Puskesmas dan Jejaringnya.

4. Dinas, K., Kabupaten, K. (2020). Rekapitulasi Laporan Ibu Bersalin dan Nifas di Puskesmas dan Jejaringnya.

5. Masrizal. (2011). Mixed Method Research. Jurnal Kesehatan Masyarakat, 6(1): 53-56. 
6. Nuryawati, L.S., dan Budiasih, S. (2017). Hubungan Kelas Ibu Hamil dengan Pengetahuan Ibu Hamil tentang Tanda-Tanda Bahaya Kehamilan di Desa Surawangi Wilayah Kerja UPTD Puskesmas Jatiwangi Kabupaten Majalengka Tahun 2016. Midwifery Journal, 3(1), 60-66.

7. Toemandoek, J.P., Wagey, F., dan Loho, M. (2015). Pengetahuan dan Sikap Bidan mengenai Penggunaan Partograf dalam Persalinan di Puskesmas PONED Kota Manado. Jurnal e-Clinic (eCl), 3(2), 735-740.

8. Silfia, N.N. (2020). Determinan Penggunaan Partograf dalam Persalinan oleh Bidan Praktik Mandiri di Kota Palu. Jurnal Bidan Cerdas, 2(2), 72-80.

9. Pinaringsih, T., Riyanti, E., dan Kusumawati, A. (2017). Faktor-Faktor yang Berhubungan dengan
Niat Kunjungan Nifas ke Pelayanan Kesehatan di Wilayah Kerja Puskesmas Tlogosari Kulon Kota Semarang. Jurnal Kesehatan Masyarakat, 5(3), 653-660.

10. Akunga, D., Menya, D., Kabue, M. (2014). Determinants of Postnatal Care Use in Kenya. African Population Studies, 28(3), 447-459

11. Silalahi, F.Q. (2018). Asuhan Kebidanan PADA Ny.R Hamil sampai dengan Masa Nifas dan Keluarga Berencana PMB Afriana Jl.Selamat Bromo Ujung. Medan: Poltekes Kemenkes RI Medan.

12. Giri, Merry. A., Indrawan, I Wayan, A., Sutrisno. (2020). The Quality of Maternal Health Services Improves the Continuity of Midwifery Services at the Community Health Center in Kupang City, East Nusa Tenggara, Indonesia. EAS Journal of Nursing and Midwifwery, 2(4), 56-59. 